\title{
Set-up and preliminary results of mid-Pliocene climate simulations with CAM3.1
}

\author{
Q. Yan ${ }^{1,2}$, Z. S. Zhang ${ }^{3,1}$, H. J. Wang ${ }^{1,4}$, Y. Q. Gao ${ }^{5,1}$, and W. P. Zheng ${ }^{6}$ \\ ${ }^{1}$ Nansen-Zhu International Research Centre, Institute of Atmospheric Physics, Chinese Academy of Sciences, \\ Beijing 100029, China \\ ${ }^{2}$ Graduate School of Chinese Academy of Sciences, Beijing 100049, China \\ ${ }^{3}$ Bjerknes Centre for Climate Research, UniResearch, Bergen 5007, Norway \\ ${ }^{4}$ Climate Change Research Center, Chinese Academy of Sciences, Beijing 100029, China \\ ${ }^{5}$ Nansen Environmental and Remote Sensing Center/Bjerknes Centre for Climate Research, Bergen 5006, Norway \\ ${ }^{6}$ State Key Laboratory of Numerical Modeling for Atmospheric Sciences and Geophysical Fluid Dynamics, \\ Institute of Atmospheric Physics, Chinese Academy of Sciences, Beijing 100029, China
}

Correspondence to: Z. S. Zhang (zhongshi.zhang@bjerknes.uib.no)

Received: 8 November 2011 - Published in Geosci. Model Dev. Discuss.: 5 December 2011

Revised: 8 February 2012 - Accepted: 8 February 2012 - Published: 9 March 2012

\begin{abstract}
The mid-Pliocene warm period $(\sim 3.264$ to $3.025 \mathrm{Ma})$ is a potential analogue for future climate under global warming. In this study, we use an atmospheric general circulation model (AGCM) called CAM3.1 to simulate the mid-Pliocene climate with the PRISM3D boundary conditions. The simulations show that the global annual mean surface air temperature (SAT) increases by $2.0^{\circ} \mathrm{C}$ in the mid-Pliocene compared with the pre-industrial temperature. The greatest warming occurs at high latitudes of both hemispheres, with little change in SAT at low latitudes. The equator-to-pole SAT gradient is reduced in the mid-Pliocene simulation. The annual mean precipitation is enhanced by $3.6 \%$ of the pre-industrial value. However, the changes in precipitation are greater at low latitudes than at high latitudes.
\end{abstract}

\section{Introduction}

Mid-Pliocene, spanning from 3.264 to $3.025 \mathrm{Ma}$ (Dowsett et al., 2010), was the most recent period with sustained warmth during Earth's history. This period has been a focus of data synthesis (e.g. Dowsett and Poore, 1991; Dowsett et al., 1992, 1996, 1999, 2009, 2010) and paleoclimate modeling (e.g. Chandler et al., 1994; Haywood and Valdes, 2004; Haywood et al., 2000; Lunt et al., 2010) efforts for the last two decades. The period has been characterized as having an increased sea surface temperature (SST) in mid-high latitudes resulting in seasonally ice-free conditions, greatly reduced ice sheets leading to a sea level rise of $25 \mathrm{~m}$, and an obvious expansion of warmth/moisture loving vegetation in the northern high latitudes (Dowsett et al., 2010). The mid-Pliocene warm period is considered the most accessible example of a world analogous to the predicted warming at the end of this century, as the mean global temperatures are estimated to be $2-3{ }^{\circ} \mathrm{C}$ above pre-industrial temperatures (Jansen et al., 2007). Mid-Pliocene also provides a chance to assess the reliability of climate models for projecting future climates. Understanding the climate of the mid-Pliocene offers the potential for us to understand the future climate change better.

Data synthesis and modeling studies for the mid-Pliocene started in the 1990s. The first reconstruction work, PRISM0 (Pliocene Research Interpretation and Synoptic Mapping, version 0) (Dowsett et al., 1994), was completed in 1994. Then, the PRISM1 (Dowsett et al., 1996) and PRISM2 (Dowsett et al., 1999) datasets were published in 1996 and 1999, respectively. Based on these reconstructions, the midPliocene climate has been widely simulated using climate models (e.g. Chandler et al., 1994; Haywood et al., 2000; Haywood and Valdes, 2004; Jiang et al., 2005; Sloan et al., 1996; Yan et al., 2011).

After the PRISM3D reconstruction (Dowsett et al., 2010) was released, the Pliocene Paleoclimate Modeling Intercomparison Project (PlioMIP) started in 2010. Using the PRISM3D data, which represent the latest global 
paleoclimate reconstruction for the mid-Pliocene, PlioMIP aims to systematically study the climate features and mechanisms of the mid-Pliocene with model-data and model-model comparisons. Thus, PlioMIP provides an opportunity to better understand the past warm climate and to reduce uncertainties in interpreting the mid-Pliocene climate.

Here, we report our simulations on mid-Pliocene climate following the PlioMIP guidelines for Experiment I (Haywood et al., 2010). We carry out the simulations with an Atmospheric General Circulation Model (AGCM) CAM3.1 (Community Atmosphere Model version 3.1) based on the latest PRISM3D reconstruction. We organize the paper as follows: we give a detailed description of the CAM3.1 model and the experimental set-up in Sects. 2 and 3, respectively. In Sect. 4, we present the preliminary results, followed by a discussion on the Hadley circulation in Sect. 5. We conclude this study in Sect. 6.

\section{Model description}

We use the Community Atmosphere Model version 3.1 (CAM 3.1) in this study to simulate the mid-Pliocene climate. CAM3.1 was developed by the National Center for Atmosphere Research in collaboration with the climate modeling community, and it is integrated with the Community Land Model version 3 (CLM3; Bonan et al., 2002a, b), a thermodynamic sea ice model and a data ocean (fixed SSTs). The thermodynamic sea ice model for CAM3.1, derived from the Community Sea Ice Model version 5 (Briegleb et al., 2004), is used to calculate energy fluxes between the ice and the overlying atmosphere.

CAM3.1 uses the spectral Eulerian dynamical core and employs a T42 spectral truncation with 26 vertical levels, which corresponds to a horizontal resolution of approximately $2.8^{\circ}$ latitude $\times 2.8^{\circ}$ longitude. Compared with the earlier version of CAM2.0, CAM3.1 employs the prognostic cloud water parameterization. The radiative parameterizations include new treatments of the interactions of shortwave and longwave radiation with cloud geometry and with water vapor. In addition, the uniform background aerosol is replaced by a present-day climatology in calculating shortwave fluxes and the heating rate. Furthermore, a careful formulation of the vertical diffusion of dry static energy and a clean separation between the physics and dynamics are implemented into CAM3.1. Note that simulations produced by CAM3.1 are almost identical to simulations produced by CAM3.0 in configurations for which control simulations were provided. A more complete description of the physical basis and numerical implementation is given in Collins et al. (2004).

CAM3.1 reasonably simulates the present climate and captures major features of the observed climatology (e.g. Collins et al., 2006; Wei et al., 2011), and has been widely used in paleoclimate studies (e.g. Caballero and Huber, 2010;
Diffenbaugh and Ashfaq, 2007; Donohoe and Battisti, 2009; Huber and Caballero, 2011; Jochum et al., 2009; You et al., 2009).

\section{Experimental design}

\subsection{Pre-industrial experiment}

\subsubsection{Ocean conditions}

In the pre-industrial run, we use the default SST and sea ice concentrations in CAM3.1 (Collins et al., 2006). These SST and sea ice concentrations are the monthly climatology for the period 1950 through 2001 calculated from the datasets, which combine the global Hadley Centre Sea Ice and Sea Surface Temperature (HadISST) dataset (Rayner et al., 2003) for years up to 1981 and the Reynolds et al. (2002) dataset after 1981. We set the sea ice thicknesses to $2 \mathrm{~m}$ in the Northern Hemisphere and $0.5 \mathrm{~m}$ in the Southern Hemisphere according to Collins et al. (2006).

\subsubsection{Geographic boundary conditions}

We convert the GTOPO30 dataset, which is a global digital elevation model with a resolution of 30 arc seconds, to a 10min grid. Then we use the interpolated data to create the surface topography and the standard deviation of the surface topography with a resolution of T42. The land-sea mask is derived from the same data. In the model configuration, the Central American Seaway (Panama Gateway) remains closed while the Bering Strait, Madagascar Strait, Drake Passage, Tasman Gateway, Gibraltar Strait and Indonesian Gateway remain open.

We create the land surface information for the preindustrial experiment based on the methods/tools provided by the CESM (Community Earth System Model) paleoclimate working group. First, we construct the Land Surface Model (LSM) land cover types from modern biome types (Matthews, 1985) provided by PRISM3D for each grid (https://wiki.ucar.edu/display/paleo/Biome4+ conversion+to+LSM). Because CLM3 represents vegetation in a grid cell as mixtures of up to 16 plant functional types (PFTs; Bonan et al., 2002a, b), whereas LSM uses an integer value to represent land cover at each grid point, we convert the LSM vegetation types to CLM3 PFTs (http://www.cgd. ucar.edu/ccr/paleo/Notes/lsm2clm.txt). Meanwhile, according to the constructed CLM3 PFTs, we calculate the corresponding leaf/stem areas and heights for each PFT using the physiological parameters obtained from Bonan (1996). Lakes, urban areas and wetlands are specified as being absent. Subsequently, we construct the soil texture by interpolating the modern soil texture (percent sand, silt, and clay) profiles (Global Soil Data Task, 2000) from a 10-min grid to 
a resolution of $2^{\circ} \times 2^{\circ}$. Finally, a land surface file, recognized by CLM3, is created and converted to the resolution of T42 at the model runtime using the above-created land surface files.

\subsubsection{Other boundary conditions}

For greenhouse gases, we set the atmospheric $\mathrm{CO}_{2}$ concentration to $280 \mathrm{ppmv}, \mathrm{N}_{2} \mathrm{O}$ concentration to $270 \mathrm{ppbv}$ and $\mathrm{CH}_{4}$ concentration to $760 \mathrm{ppbv}$. The SUNYA ozone data climatology (Liang et al., 1997) is adopted in the pre-industrial run.

We set the orbital parameters to the values for the year 1950 and the solar constant to $1365 \mathrm{~W} \mathrm{~m}^{-2}$. The aerosol dataset is derived from a chemical transport model constrained by the assimilation of satellite retrievals of aerosol depth for the period 1995-2000.

\subsection{Mid-Pliocene experiment}

\subsubsection{Ocean conditions}

Using the anomaly method, we first calculate the SST anomalies between the PRISM3D mid-Pliocene (Dowsett, 2007; Robinson et al., 2008; Dowsett et al., 2009) and the PRISM3D present SST (Reynolds and Smith, 1995), and we interpolate the derived SST anomalies to the resolution of CAM3.1 (T42). Then, we add the interpolated anomalies to the HadISST fields, which are the climatological monthly mean SST used in the pre-industrial experiment, to create the SST for the mid-Pliocene experiment. We set the sea ice coverage conditions based on the rebuilt SST in the midPliocene. If the SST in the mid-Pliocene is higher than $-1.8^{\circ} \mathrm{C}$, we set the sea ice coverage to 0 . The reconstructed sea ice coverage shows an ice-free Arctic in boreal summer.

\subsubsection{Geographic boundary conditions}

To create the surface topography for the mid-Pliocene experiment, we first calculate the topography anomalies between the PRISM3D mid-Pliocene (Sohl et al., 2009) and PRISM3D present topography (Edwards, 1992). Then, we interpolate the anomalies to the T42 resolution and add them to the present topography in the pre-industrial experiment. Note that the land-sea mask remains as the same as in the pre-industrial experiment.

For the land cover in the mid-Pliocene, the same methods as in the pre-industrial experiment are adopted. First, we convert the reconstructed mid-Pliocene land cover (Hill et al., 2007; Salzmann et al., 2008) to LSM land cover types for each grid. Then, the LSM land cover types are converted to the CLM3 PFTs. Subsequently, according to the constructed CLM3 PFTs, we calculate the corresponding leaf/stem areas and heights for each PFT still using modern physiological parameters. We set the percentages of lakes, urban areas and wetlands to zero. Soil color and soil texture are specified as the same as in the pre-industrial run. Finally, a land surface

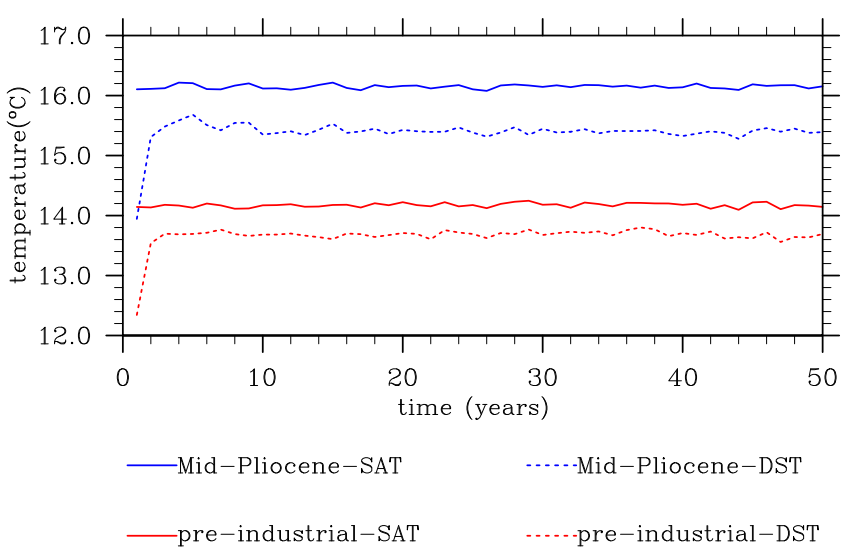

Fig. 1. Time series of global annual mean surface air temperature $\left({ }^{\circ} \mathrm{C}\right)$ and the deepest soil temperature (DST, $\left.{ }^{\circ} \mathrm{C}\right)$ in the preindustrial and mid-Pliocene experiments.

file is created and tailored to the land and ocean grids (T42) at the model runtime using the above-created land surface files.

The rebuilt mid-Pliocene land cover shows greatly reduced ice volume and ice area in Greenland and Antarctic, an obvious expansion of warmth/moisture-loving vegetation in the northern high latitudes and much smaller deserts in Africa, Australia and central Asia.

\subsubsection{Other boundary conditions}

For the greenhouse gases, the atmospheric $\mathrm{CO}_{2}$ concentration increases to $405 \mathrm{ppmv}$, with the $\mathrm{N}_{2} \mathrm{O}$ concentration, $\mathrm{CH}_{4}$ concentration and ozone unchanged compared with the pre-industrial run. The orbital parameters, solar constant and aerosol datasets are all kept as the same as in the preindustrial run.

The two experiments have been integrated for $50 \mathrm{yr}$. A detailed experimental design is summarized in Table 1.

\section{Results}

Both time series of the surface air temperature (SAT) and deepest soil temperature (DST) indicate that the model has reached equilibrium (Fig. 1). Here, we calculate the climatological means from the last $30-y r$ results in each experiment. The results show that the annual mean net energy at the top of the atmosphere is $1.2 \mathrm{~W} \mathrm{~m}^{-2}$ and $4.1 \mathrm{~W} \mathrm{~m}^{-2}$ in the pre-industrial and mid-Pliocene experiments, respectively. The global annual mean SAT increases by $2.0^{\circ} \mathrm{C}$ in the mid-Pliocene compared with the pre-industrial run. The global annual mean precipitation increases by $3.6 \%$ of the pre-industrial value (Table 2). 
Table 1. Summary of the experimental design.

\begin{tabular}{lll}
\hline Boundary conditions & pre-industrial & mid-Pliocene \\
\hline SST & local modern & PRISM3_SST_v1.3.nc \\
Land-sea mask & local modern & local modern \\
Topography & local modern & topo_v1.4 \\
Ice sheets and vegetation & BAS_Observ_BIOME & biome_veg_v1.2 \\
Greenhouse gases & $\mathrm{CO}_{2}=280 \mathrm{ppm}, \mathrm{N}_{2} \mathrm{O}=270 \mathrm{ppb}$, & $\mathrm{CO}_{2}=405 \mathrm{ppm}, \mathrm{N}_{2} \mathrm{O}=270 \mathrm{ppb}$, \\
& $\mathrm{CH}_{4}=760 \mathrm{ppb}, \mathrm{CFCs}=0$, & $\mathrm{CH}_{4}=760 \mathrm{ppb}, \mathrm{CFCs}=0$, \\
& $\mathrm{O}_{3}=$ local modern & $\mathrm{O}_{3}=$ local modern \\
Solar constant & $1365 \mathrm{~W} \mathrm{~m}-2$ & $1365 \mathrm{~W} \mathrm{~m}^{-2}$ \\
Aerosols & local modern & local modern \\
Orbital Parameters & ecc $=0.016724, \mathrm{obl}=23.446^{\circ}$, & ecc $=0.016724, \mathrm{obl}^{\circ}=23.446^{\circ}$, \\
& peri $-180^{\circ}=102.04^{\circ}$ & peri $-180^{\circ}=102.04^{\circ}$ \\
\hline
\end{tabular}

Table 2. Global annual mean of net energy at the top of atmosphere (TOA), surface air temperature (SAT) and precipitation rate (Prec) for the pre-industrial, mid-Pliocene, and the differences between mid-Pliocene and pre-industrial.

\begin{tabular}{lrrc}
\hline Experiments & $\begin{array}{r}\text { TOA } \\
\left(\mathrm{Wm}^{-2}\right)\end{array}$ & $\begin{array}{r}\text { SAT } \\
\left({ }^{\circ} \mathrm{C}\right)\end{array}$ & $\begin{array}{c}\text { Prec } \\
\left(\mathrm{mm} \mathrm{day}^{-1}\right)\end{array}$ \\
\hline Pre-industrial & 1.2 & 14.2 & 2.8 \\
Mid-Pliocene & 4.1 & 16.2 & 2.9 \\
Differences & 2.9 & 2.0 & 0.1 \\
\hline
\end{tabular}

\subsection{Surface air temperature}

For the zonal mean SAT, the CAM3.1 model simulates a distinct pattern of mid to high latitude warming over oceans and continents in the mid-Pliocene (Fig. 2). The maximum warming in the zonal mean SAT is located in the high latitudes, where the SAT increases by approximately $10^{\circ} \mathrm{C}$ (at approximately $80^{\circ} \mathrm{N}$ ) and $8^{\circ} \mathrm{C}$ (at approximately $70^{\circ} \mathrm{S}$ ). However, the SAT remains nearly unchanged in the low latitudes. The equator-to-pole SAT gradient, defined as the SAT differences between $0-30^{\circ} \mathrm{N}(\mathrm{S})$ and $60^{\circ}-90^{\circ} \mathrm{N}(\mathrm{S})$, decreases by $7.3^{\circ} \mathrm{C}$ and $4.1^{\circ} \mathrm{C}$ in the Northern Hemisphere and Southern Hemisphere, respectively.

The strong high latitude warming can also be observed in the spatial distribution of SAT anomalies between the midPliocene and pre-industrial experiments (Fig. 3). Between $40^{\circ} \mathrm{N}$ and $90^{\circ} \mathrm{N}$, the annual mean SAT is approximately 2$16^{\circ} \mathrm{C}$ higher in the mid-Pliocene than in pre-industrial. The greatest warming appears in Greenland and the sub-polar North Atlantic, with a rise of $8^{\circ} \sim 16^{\circ} \mathrm{C}$. Between $40^{\circ} \mathrm{S}$ and $40^{\circ} \mathrm{N}$, the SAT increases by $0-2^{\circ} \mathrm{C}$ in most regions. Between $40^{\circ} \mathrm{S}$ and $80^{\circ} \mathrm{S}$, the SAT rises by approximately 4 $18^{\circ} \mathrm{C}$. The greatest warming compared with pre-industrial occurs in the margins of the East Antarctic and West Antarctic, where the SAT is $8-18^{\circ} \mathrm{C}$ and $6-12^{\circ} \mathrm{C}$ higher, respectively. The great warming over Greenland and Antarctic is attributed to the combined effects of reduced surface albdo and lower topography in the mid-Pliocene.

However, cooling is still apparent in some local regions in the mid-Pliocene. The SAT decreases by $0-2{ }^{\circ} \mathrm{C}$ over the East African rift zone and the western tropical Pacific. The SAT remains nearly unchanged or exhibits slight cooling at $80^{\circ}-90^{\circ} \mathrm{S}$ in the East Antarctic.

During boreal winter (Fig. 3), the globally averaged SAT compared with the pre-industrial rises on average by $2.0^{\circ} \mathrm{C}$. The extreme warming over the high latitudes of the Northern Hemisphere becomes stronger in comparison with the changes in annual mean SAT, with a maximum warming of $\sim 20^{\circ} \mathrm{C}$ over the sub-polar North Atlantic. The warming areas also expand. In low latitudes, the magnitude of warming is unchanged. In contrast, the magnitude of warming in the Southern Hemisphere between $60^{\circ} \mathrm{S}$ and $90^{\circ} \mathrm{S}$ decreases by about $2-3{ }^{\circ} \mathrm{C}$.

During boreal summer, the averaged SAT increases by $1.9^{\circ} \mathrm{C}$ compared with the pre-industrial (Fig. 3). Compared to the annual mean SAT anomalies, the summer warming is weaker in the northern high latitudes, especially over the Arctic. In contrast, the warming magnitude over the Antarctic increases dramatically $\left(10-18^{\circ} \mathrm{C}\right)$, together with the expansion of warming areas. It is noted that the annual, winter and summer mean surface warming are generally consistent in the low latitudes, and the discrepancies are mainly found in the high latitudes. Additionally, the high latitude warming in the mid-Pliocene is stronger in boreal winter than in boreal summer, which is caused by the fact that increased SST and reduced sea-ice have their maximum effects on air temperature in boreal winter. 

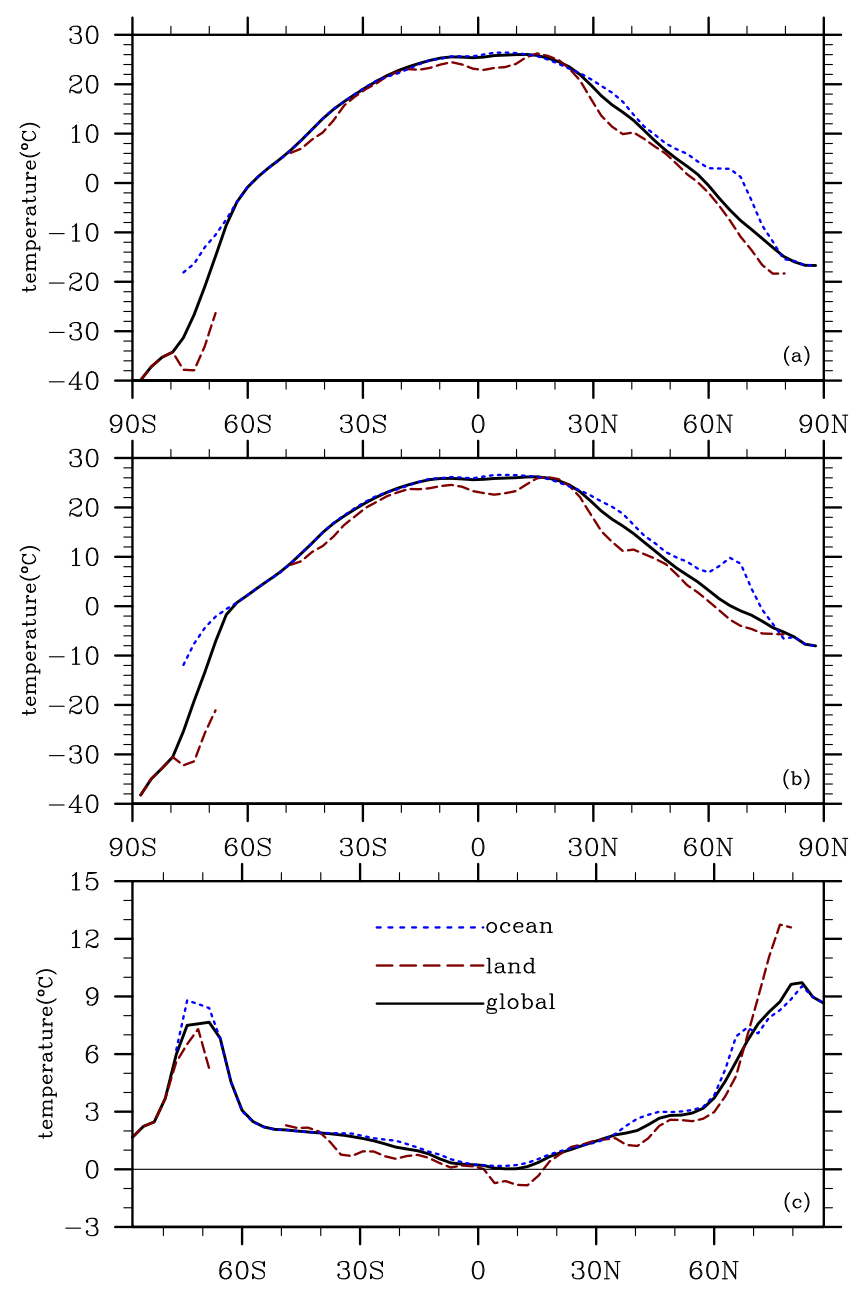

Fig. 2. Zonal mean surface air temperature $\left({ }^{\circ} \mathrm{C}\right)$ in the preindustrial experiment (a), the mid-Pliocene experiment (b) and the anomalies between the mid-Pliocene and pre-industrial (c).

\subsection{Precipitation}

Compared with pre-industrial, annual mean precipitation is enhanced over the continents in the mid-Pliocene, with great increases $\left(0.8-1.6 \mathrm{~mm} \mathrm{day}^{-1}\right)$ over South Greenland, Africa, the Middle-East region, Australia and the west coast of South America (Fig. 4). Over the oceans, the precipitation is enhanced $\left(\sim 3.0 \mathrm{~mm} \mathrm{day}^{-1}\right)$ over the sub-polar North Atlantic and the cold tongue in the eastern tropical Pacific. In contrast, the precipitation decreases significantly by 0.8 $3 \mathrm{~mm} \mathrm{day}^{-1}$ and $0.2-2.6 \mathrm{~mm} \mathrm{day}^{-1}$ over the North Indian Ocean and the InterTropical Convergence Zone (ITCZ), respectively. Decreased precipitation is also simulated in the tropical Atlantic. Generally, the changes in precipitation are greater at low latitudes than at high latitudes.

During boreal winter (Fig. 4), the spatial distribution and magnitude of precipitation anomalies are nearly unchanged compared with the anomalies of the annual mean precipitation. During boreal summer (Fig. 4), the precipitation

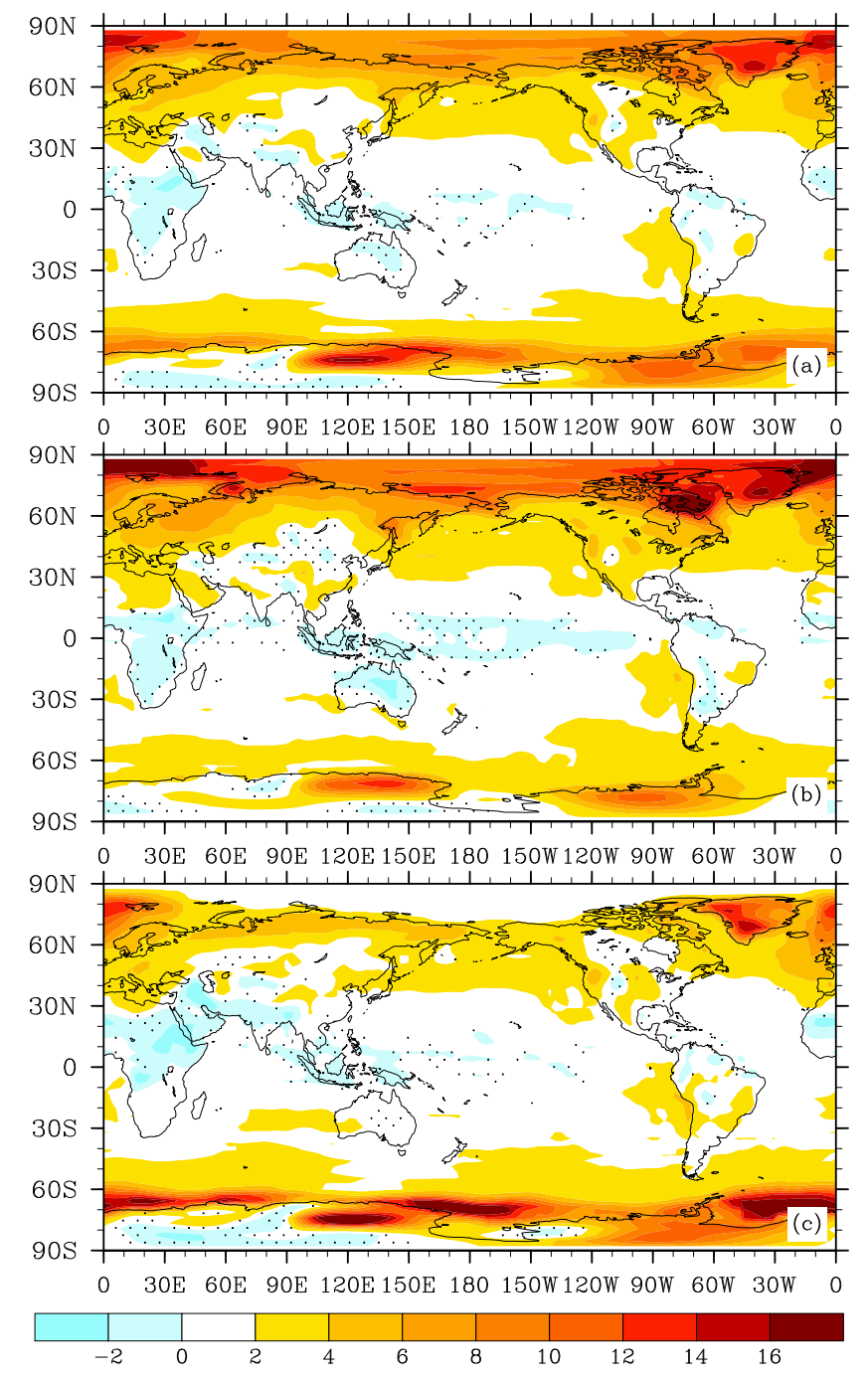

Fig. 3. Surface air temperature anomaly $\left({ }^{\circ} \mathrm{C}\right)$ between the midPliocene experiment and the pre-industrial experiment for the annual period (a), winter (b) and summer (c) seasons. Areas with a confidence level less than $95 \%$ are dotted.

decreases much more $\left(>3.2 \mathrm{~mm} \mathrm{day}^{-1}\right)$ over the North Indian Ocean and the ITCZ compared with the changes in annual mean precipitation. In contrast, the precipitation is enhanced over North Africa, the Middle-East region, Indonesia, and the adjacent oceans. The area of enhanced precipitation over the sub-polar Atlantic becomes smaller. However, the global mean summer precipitation remains unchanged compared with the pre-industrial.

\section{Discussion}

As the reconstruction and our simulation illustrate, substantial warming $\left(8-16^{\circ} \mathrm{C}\right)$ is located in the high latitudes in the mid-Pliocene, with the slight warming $\left(0-2{ }^{\circ} \mathrm{C}\right)$ in low 


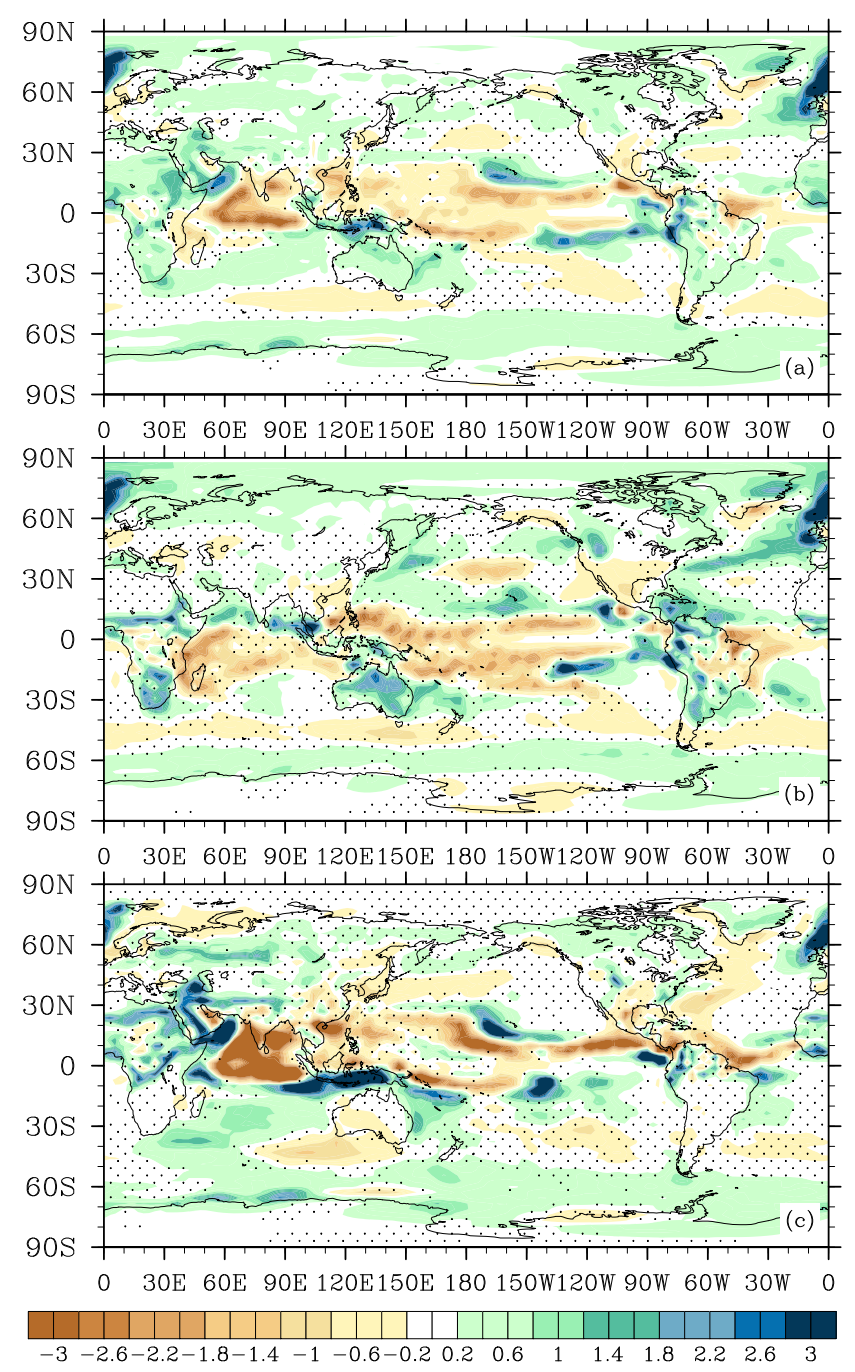

Fig. 4. Same as in Fig. 3 but for the precipitation anomaly $\left(\mathrm{mm} \mathrm{day}^{-1}\right)$.

latitudes. Thus, the equator-to-pole temperature gradient is reduced.

Due to the reduced temperature gradient, the Hadley circulation slows down in the mid-Pliocene compared with the pre-industrial circulation. Both the ascending branches of the Hadley cell near $10^{\circ} \mathrm{S}-15^{\circ} \mathrm{N}$ and the descending branches at approximately $15^{\circ} \mathrm{N}-25^{\circ} \mathrm{N}$ and $10^{\circ} \mathrm{S}-20^{\circ} \mathrm{S}$ are weakened (Fig. 5). The weakened descending branches of the Hadley cell enhance precipitation in the subtropics. The weakened ascending branches of the Hadley cell (approximately $10^{\circ} \mathrm{S}-$ $15^{\circ} \mathrm{N}$ ) lead to weakened deep convection over ITCZ, which in turn causes decreased precipitation over ITCZ. In addition, the slow-down of the Hadley cell leads to weakened surface winds, namely trade winds, in the tropics. However, it should be noted that the sinking motion at the poleward edge of the Hadley cell (approximately $30^{\circ} \mathrm{N}$ and $30^{\circ} \mathrm{S}$ ) is strengthened (Fig. 5), which may indicate the poleward expansion of the Hadley cell.

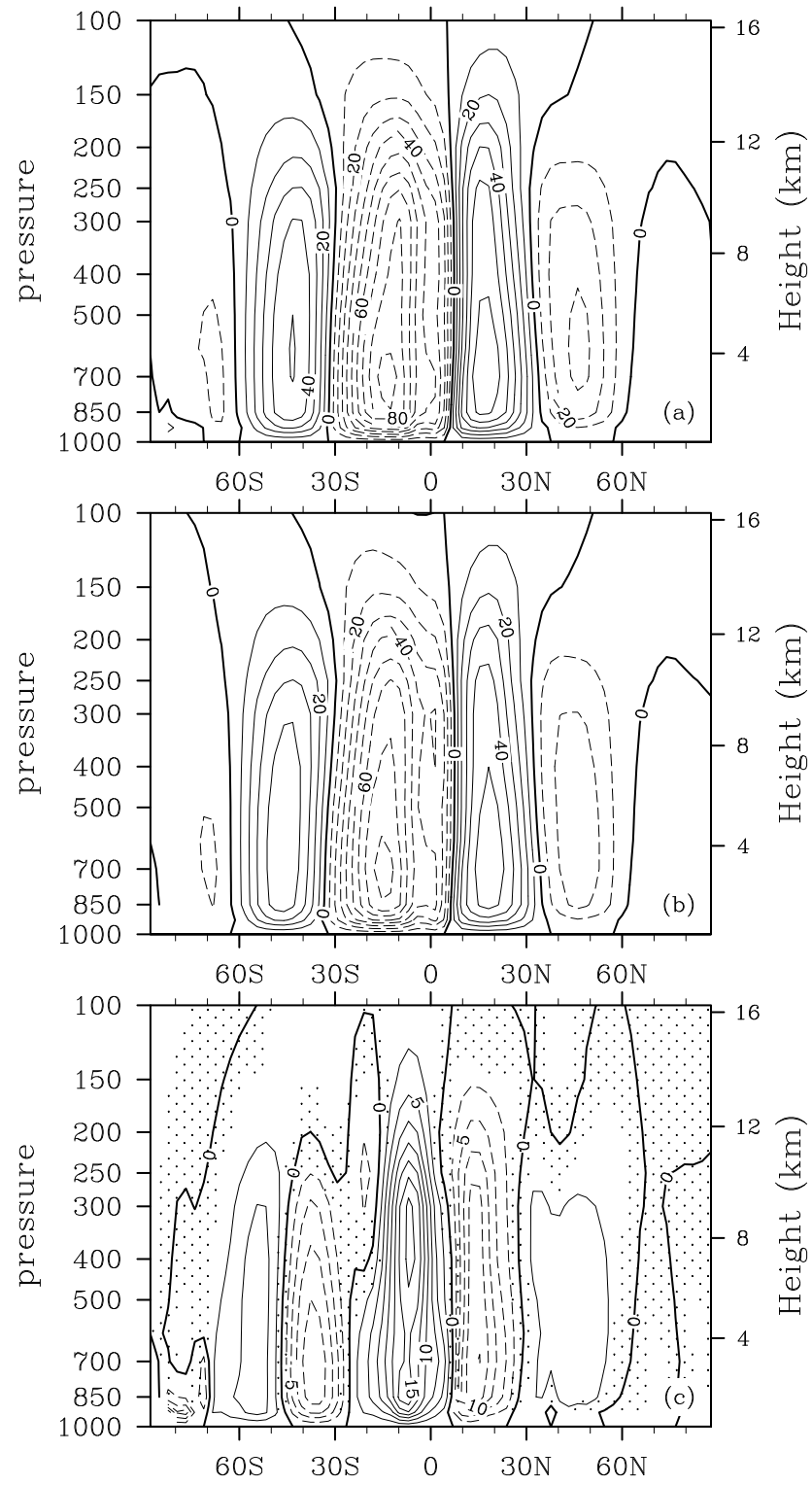

Fig. 5. Mass stream function $\left(\times 10^{9} \mathrm{~kg} \mathrm{~s}^{-1}\right)$ of the annually averaged zonal mean meridional circulation in the pre-industrial (a), the mid-Pliocene (b) and the differences between the mid-Pliocene and pre-industrial (c). Areas with a confidence level less than $95 \%$ are dotted.

To quantify the expansion of the Hadley cell, we utilize two methods to define the Hadley cell edges. The first is to find the latitudes where the mass stream function of the Mean Meridional Circulation (MMC) in the troposphere (at $500 \mathrm{hPa}$ ) becomes zero poleward of the subtropical maxima (Lu et al., 2007; Johanson and Fu, 2009). The other method is to find the latitudes where the outgoing longwave radiation reaches $250 \mathrm{~W} \mathrm{~m}^{-2}$ in each hemisphere's subtropical transition zone (Lu et al., 2007; Johanson and Fu, 2009). The results show that based on calculated mass stream function, the 


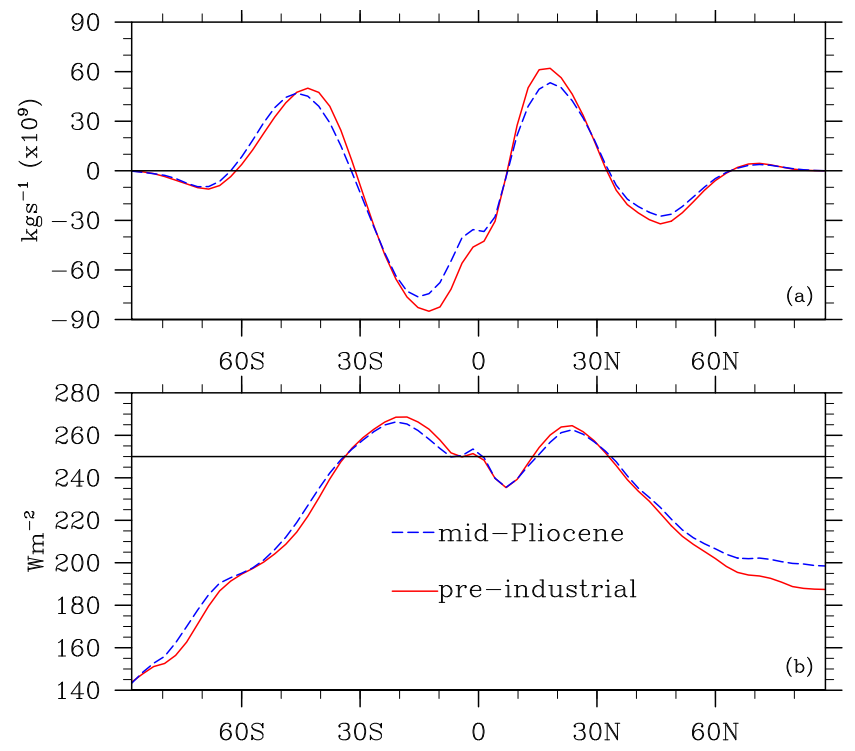

Fig. 6. (a): latitudinal cross-section of the mass stream function at $500 \mathrm{hPa}$ in the pre-industrial and mid-Pliocene. (b): zonal mean outgoing longwave radiation in the pre-industrial and mid-Pliocene.

descending branches of the Hadley cell in the mid-Pliocene expand poleward by $0.4^{\circ}$ and $1.0^{\circ}$ in the northern and southern hemispheres, respectively, while expand poleward by $0.6^{\circ}$ and $0.2^{\circ}$ based on the simulated outgoing longwave radiation (Fig. 6).

The poleward expansion of the Hadley cell is potentially important for understanding future climate under global warming (Seidel et al., 2008; Johanson and Fu, 2009). As the Hadley cell has widened by about $2^{\circ}-5^{\circ}$ since 1979 based on recent observations (Johanson and $\mathrm{Fu}, 2009$ ), the poleward expansion of the Hadley cell in the mid-Pliocene is not significant. However, it should be noted that the simulation for the Hadley circulation here is mainly controlled by the prescribed PRISM3D SST fields. Due to the uncertainties in the reconstruction of the PRISM3D SST, it remains a task to compare our simulation with other coupled simulations.

\section{Summary}

In this study, using AGCM CAM3.1, we simulate the midPliocene climate with the prescribed PRISM3D boundary conditions. Our simulations illustrate that the global annual mean SAT in the mid-Pliocene is approximately $2.0^{\circ} \mathrm{C}$ higher than the pre-industrial value. The warming is stronger in the mid-high latitudes than in the low latitudes, which leads to a reduced equator-to-pole SAT gradient. The annual mean precipitation increases by $3.6 \%$ of the pre-industrial value. However, the changes in precipitation are much greater at low latitudes than at high latitudes. Moreover, the Hadley cell expands poleward by less than $1^{\circ}$ in the midPliocene compared to pre-industrial.
Acknowledgements. The authors would like to thank the PRISM workgroup for providing the mid-Pliocene boundary conditions and the CESM paleoclimate workgroup for providing the tools which were used to create boundary conditions for CAM3.1. The comments of the Topical editor, René Redler, and the reviewers, H. Dowsett and M. Krapp, helped considerably to improve the clarity of the manuscript. This work was supported by the National Basic Research Program of China (2009CB421406), the Knowledge Innovation Program of the Chinese Academy of Sciences (KZCX2-YW-Q1-02), and the National Natural Science Foundation of China (4090205 and 40975050).

Edited by: R. Redler

\section{References}

Bonan, G. B.: Land surface model (LSM version 1.0) for ecological, hydrological, and atmospheric studies: Technical description and users guide, NCAR Technical Note NCAR/TN-417+STR, National Center for Atmospheric Research, Boulder, Colorado, 150 pp., 1996.

Bonan, G. B., Levis, S., Kergoat, L., and Oleson, K. W.: Landscapes as patches of plant functional types: An integrating concept for climate and ecosystem models, Global Biogeochem. Cy., 16, 1021, doi:10.1029/2000GB001360, 2002a.

Bonan, G. B., Oleson, K. W., Vertenstein, M., Levis, S., Zeng, X., Dai, Y., Dickinson, R. E., and Yang, Z. L.: The land surface climatology of the community land model coupled to the NCAR community climate model, J. Climate, 15, 3123-3149, 2002b.

Briegleb, B. P., Bitz, C. M., Hunke, E. C., Lipscomb, W. H., Holland, M. M., Schramm, J. L., and Moritz, R. E.: Scientific description of the sea ice component in the community climate system model, version Three, Technical Note NCAR/TN-463+STR, National Center for Atmospheric Research, Boulder, Colorado, 78 pp., 2004.

Caballero, R. and Huber, M.: Spontaneous transition to superrotation in warm climates simulated by CAM3, Geophys. Res. Lett., 37, L11701, doi:10.1029/2010GL043468, 2010.

Chandler, M., Rind, D., and Thompson, R.: Joint investigations of the middle Pliocene climate II: GISS GCM Northern Hemisphere results, Global Planet. Change, 9, 197-219, 1994.

Collins, W. D., Rasch, P. J., Boville, B. A., Hack, J. J., McCaa, J. R., Williamson, D. L., Kiehl, J. T., Briegleb, B., Bitz, C., and Lin, S.: Description of the NCAR community atmosphere model (CAM 3.0), NCAR Technical Note NCAR/TN-464+STR, National Center for Atmospheric Research, Boulder, Colorado, 226 pp., 2004.

Collins, W. D., Rasch, P. J., Boville, B. A., Hack, J. J., McCaa, J. R., Williamson, D. L., Briegleb, B. P., Bitz, C. M., Lin, S. J., and Zhang, M.: The formulation and atmospheric simulation of the Community Atmosphere Model version 3 (CAM3), J. Climate, 19, 2144-2161, 2006.

Diffenbaugh, N. S. and Ashfaq, M.: Response of California Current forcing to mid-Holocene insolation and sea surface temperatures, Paleoceanography, 22, PA3101, doi:10.1029/2006PA001382, 2007.

Donohoe, A. and Battisti, D. S.: Causes of reduced North Atlantic storm activity in a CAM3 simulation of the Last Glacial Maximum, J. Climate, 22, 4793-4808, 2009. 
Dowsett, H. J.: The PRISM palaeoclimate reconstruction and Pliocene sea-surface temperature, in: Deep time perspectives on climate change: Marrying the signal from computer models and biological proxies, edited by: Williams, M., Haywood, A. M., Gregory, F. J., and Schmidt, D. N., the Micropalaeontological Society, Special Publications, the Geological Society, London, 459-480, 2007.

Dowsett, H. J. and Poore, R. Z.: Pliocene sea surface temperatures of the North Atlantic Ocean at 3.0 Ma., Quaternary Sci. Rev., 10, 189-204, 1991.

Dowsett, H. J., Cronin, T. M., Poore, R. Z., Thompson, R. S., Whatley, R. C., and Wood, A. M.: Micropaleontological evidence for increased meridional heat transport in the North Atlantic Ocean during the Pliocene, Science, 258, 1133-1135, 1992.

Dowsett, H. J., Thompson, R., Barron, J., Cronin, T., Fleming, F., Ishman, S., Poore, R.,Willard, D., and Holtz, T.: Joint investigations of the middle Pliocene climate I: PRISM paleoenvironmental reconstructions, Global Planet. Change, 9, 169-195, 1994.

Dowsett, H. J., Barron, J., and Poore, R.: Middle Pliocene sea surface temperatures: a global reconstruction, Mar. Micropaleontol., 27, 13-25, 1996.

Dowsett, H. J., Barron, J. A., Poore, R. Z., Thompson, R. S., Cronin, T. M., Ishman, S. E., and Willard, D. A.: Middle Pliocene paleoenvironmental reconstruction: PRISM2, US Geol. Surv., Open File Rep., 99-535, 1999.

Dowsett, H. J., Robinson, M. M., and Foley, K. M.: Pliocene threedimensional global ocean temperature reconstruction, Clim. Past, 5, 769-783, doi:10.5194/cp-5-769-2009, 2009.

Dowsett, H. J., Robinson, M. M., Haywood, A. M., Salzmann, U., Hill, D., Sohl, L., Chandler, M., Williams, M., Foley, K., and Stoll, D.: The PRISM3D paleoenvironmental reconstruction, Stratigraphy, 7, 123-139, 2010.

Edwards, M.: Global Gridded Elevation and Bathymetry, Global Ecosystems Database, Version 1.0 (on CD-ROM), Documentation Manual, Disc-A: National Geophysical Data Center, Key to Geophysical Records Documentation No. 26, Incorporated in: Global Change Database, Volume 1, edited by: Kineman, J. J. and Ohrenschall, M. A., Boulder, CO, National Oceanic and Atmospheric Administration, 14-1 to A14-4, 1992.

Global Soil Data Task: Global Soil Data Products CD-ROM (IGBP-DIS), CD-ROM, International Geosphere-Biosphere Programme, Data and Information System, Potsdam, Germany, 2000.

Haywood, A. M. and Valdes, P. J.: Modelling Pliocene warmth: contribution of atmosphere, oceans and cryosphere, Earth Planet. Sci. Lett., 218, 363-377, 2004.

Haywood, A. M., Valdes, P. J., and Sellwood, B. W.: Global scale palaeoclimate reconstruction of the middle Pliocene climate using the UKMO GCM: initial results, Global Planet. Change, 25, 239-256, 2000.

Haywood, A. M., Dowsett, H. J., Otto-Bliesner, B., Chandler, M. A., Dolan, A. M., Hill, D. J., Lunt, D. J., Robinson, M. M., Rosenbloom, N., Salzmann, U., and Sohl, L. E.: Pliocene Model Intercomparison Project (PlioMIP): experimental design and boundary conditions (Experiment 1), Geosci. Model Dev., 3, 227-242, doi:10.5194/gmd-3-227-2010, 2010.

Hill, D. J., Haywood, A. M., Hindmarsh, R. C. A., and Valdes, P. J.: Characterising ice sheets during the mid Pliocene: evidence from data and models, in: Deep time perspectives on climate change:
Marrying the signal from computer models and biological proxies, edited by: Williams, M., Haywood, A. M., Gregory, F. J., and Schmidt, D. N., the Micropalaeontological Society, Special Publications, the Geological Society, London, 517-538, 2007.

Huber, M. and Caballero, R.: The early Eocene equable climate problem revisited, Clim. Past, 7, 603-633, doi:10.5194/cp-7603-2011, 2011.

Jansen, E., Overpeck, J., Briffa, K., Duplessy, J., Joos, F., MassonDelmotte, V., Olago, D., Otto-Bliesner, B., Peltier, and W., Rahmstorf, S.: Palaeoclimate, in: Climate change 2007: The Physical Science Basis, Contribution of Working Group I to the Fourth Assessment Report of the Intergovernmental Panel on Climate Change, edited by: Solomon, S., Qin, D., Manning, M., Chen, Z., Marquis, M., Averyt, K. B., Tignor, M., and Miller, H. L., Cambridge University Press, Cambridge, United Kingdom and New York, NY, USA, 440-442, 2007.

Jiang, D., Wang, H., Ding, Z., Lang, X., and Drange, H.: Modeling the middle Pliocene climate with a global atmospheric general circulation model, J. Geophys. Res., 110, D14107, doi:10.1029/2004JD005639, 2005.

Jochum, M., Fox-Kemper, B., Molnar, P., and Shields, C.: Differences in the Indonesian seaway in a coupled climate model and their relevance to Pliocene climate and El Niño, Paleoceanography, 24, PA1212, doi:10.1029/2008PA001678, 2009.

Johanson, C. M. and Fu Q.: Hadley cell widening: Model simulation versus observations, J. Climate, 22, 2713-2725, 2009.

Liang, X. Z., Wang, W. C., and Boyle, J. S.: Atmospheric ozone climatology for use in general circulation models, Tech. Rep. 43, PCMDI, 25 pp., 1997.

Lu, J., Vecchi G. A., and Reichler T.: Expansion of the Hadley cell under global warming, Geophys. Res. Lett., 34, L06805, doi:10.1029/2006GL028443, 2007.

Lunt, D. J., Haywood, A. M., Schmidt, G. A., Salzmann, U., Valdes, P. J., and Dowsett, H. J.: Earth system sensitivity inferred from Pliocene modelling and data, Nat. Geosci., 3, 60-64, 2010.

Matthews, E.: Prescription of land-surface boundary conditions in GISS GCM II: A simple method based on high-resolution vegetation data bases, NASA Report No. TM 86096, 20 pp., 1985.

Rayner, N. A., Parker, D. E., Horton, E. B., Folland, C. K., Alexander, L. V., Powell, D. P., Kent, E. C., and Kaplan, A.: Global analyses of sea surface temperature, sea ice, and night marine air temperature since the late nineteenth century, J. Geophys. Res., 108, 4407, doi:10.1029/2002JD002670, 2003.

Reynolds, R. W. and Smith, T. M.: A high-resolution global sea surface temperature climatology, J. Climate, 8, 1571-1583, 1995.

Reynolds, R. W., Rayner, N. A, Smith, T. M., Stokes, D. C., and Wang, W.: An improved in situ and satellite SST analysis for climate, J. Climate, 15, 1609-1625, 2002.

Robinson, M. M., Dowsett, H. J., Dwyer, G. S., and Lawrence, K. T.: Reevaluation of mid-Pliocene North Atlantic sea surface temperatures, Paleoceanography, 23, PA3213, doi:10.1029/2008PA001608, 2008.

Salzmann, U., Haywood, A. M., Lunt, D. J., Valdes, P. J., and Hill, D. J.: A new global biome reconstruction and data-model comparison for the middle Pliocene, Global Eco. Biogeogr., 17, 432447, 2008.

Seidel, D. J., Fu, Q., Randel, W. J., and Reichler, T. J.: Widening of the tropical belt in a changing climate, Nat. Geosci., 1, 21-24, 2008. 
Sloan, L. C., Crowley, T. J., and Pollard, D.: Modeling of middle Pliocene climate with the NCAR GENESIS general circulation model, Mar. Micropaleontol., 27, 51-61, 1996.

Sohl, L. E., Chandler, M. A., Schmunk, R. B., Mankoff, Ken, Jonas, J. A., Foley, K. M., and Dowsett, H. J.: PRISM3/GISS topographic reconstruction: US Geol. Surv. Data Series 419, 6 pp., 2009.

Wei, T., Wang, L., Dong, W., Dong, M., and Zhang J.: A comparison of East Asian summer monsoon simulations from CAM3.1 with three dynamic cores, Thero. Appl. Climatol., 106, 295-306, 2011.
Yan, Q., Zhang, Z., Wang, H., Jiang, D., and Zheng, W.: Simulation of sea surface temperature changes in the middle Pliocene warm period and comparison with reconstructions, Chinese Sci. Bull., 56, 890-899, 2011.

You, Y., Huber, M., Muller, R. D., Poulsen, C. J., and Ribbe, J.: Simulation of the Middle Miocene Climate Optimum, Geophys. Res. Lett., 36, L04702, doi:10.1029/2008GL036571, 2009. 